\title{
THE EFFECTS OF TERRORISM ON PEACE AND NATIONAL DEVELOPMENT IN NIGERIA
}

https://doi.org/10.47743/jopafl-2021-22-22

\author{
Israel Ikechukwu DIBIA \\ Institute for peace, Conflict and Development Studies \\ Faculty of Social Sciences and Humanities \\ Enugu State University of Science and Technology, Enugu \\ ibiaik9@gmail.com
}

\begin{abstract}
Issues bothering on national security are very crucial for the material progress of any polity. This assertion is against this framework of truism that sustainable development is a function of an enabling environment. It is against this backdrop that this study examined the effects of terrorism on peace and national development in the South-South geopolitical zone of Nigeria. The study employed qualitative and quantitative methods of drawing data from primary and secondary sources, reviewed existing literature from journals, online articles, and research projects. The research adopted the Frustration-Aggression theory. A cross-sectional research design was adopted and data was collected via a survey of 300 respondents in the South-South geopolitical zone of Nigeria using non-probabilistic sampling techniques. Data collected were analyzed using percentages, Pearson's Coefficient of correlation and linear regression analysis with the aid of Statistical Package for Social Sciences (SPSS) Version 23. The correlation coefficient (r) values are -0.369 and -0.353 . The results showed that there is a strong negative relationship between terrorism and peace and between terrorism and national development. On the basis of these findings, the research recommended that the Nigerian government should create employment for youths, who are unemployed in the South-South geopolitical zone andshould come up with programmes that will provide infrastructural facilities and genuine women empowerment. Corrupt politicians should be punished to serve as a lesson to others who intend to loot the nation's wealth. Government at all levels must eschew corruption in the fight against criminality, terrorism and insecurity. The democratic system in place must begin to deliver the needed social goods so as to improve the standard of living of Nigerians and deliver many citizens in the South-South geopolitical zone from absolute poverty to which they have been subjected for a long while. Government should plug all the holes through which scarce resources are being siphoned so as to free resources for national development and equipping of the military to fulfil its functions of providing peace and security to Nigerians.
\end{abstract}

Keywords: Terrorism, peace, national development, South-South

\section{Introduction}

Issues bordering on national security are very critical for the material progress of any polity. This assertion is against the backdrop of the truism that sustainable development is a function of an enabling environment. Nigeria, just like other countries, has her have their own peculiar challenges and problems. Hutchful (2002) cited in Adebayo (2014:480) is of the view that "the survival of any society is its laws and order which are imbibed on national security." Insecurity leaves in its wake the tales of woe which the country and her citizens have had to contend with over the years (Adebayo, 2014). Nigeria being a developing nation stillhas her own share of political, cultural, social and economic problems which have over the years affected its citizens (Adebayo, 2013).However, various challenges have befallen the Nigerian state which has hindered its development potentials since the country became a democratic state. These security issues range from 
armed robbery, ethnic conflicts across the different geo-political zones, kidnappings, to terrorism and insurgency in the South-South and North-Eastern parts of the country. Nigeria has a population of about 200 million, and it isAfrica's largest country in terms of demographic size. With a Gross Domestic Product(GDP) of US\$415 billion, it is the second largest economy after South Africa. Nigeria holds the record for being the largest oil producer on the continent and the sixth in Organization of the Petroleum Exporting Countries (OPEC) (Shehu, 2015:40). The country is well endowed with petroleum, gas and yet-untapped mineral resources. Its agricultural potentials are considerable, although the country remains a net importer of food. Inthe last decade, growth was $7.4 \%$ and is projected to be $6.9 \%$ by the end of 2012 (Shehu, 2015:40). Udu and Edeh (2019)as a country, there should be a target to attain some level of security by protecting its populace from crime, social insecurity, and structural violence. Indeed, without the protection and safety of citizens, plans for peace and national development will fail (Akinyetun, 2017:16). A major phenomenon bedeviling various countries across the world and mostly Africa in varying levels as it affects policies and development is the issue of insecurity. Reducing the rate of crimes to the barest minimum is what any nation is striving towards development should target (Awojobi, 2014:144). The magnitude of the insecurity situation in the country has become so grave that the Army, Police Force, Air Force etcetera. have all been drafted into maintaining internal security. This has led to palpable fear among the people as security of lives and properties can no longer be guaranteed. The phenomenon of crime has impacted negatively on the political, economic and social life of Nigerians (Shehu, 2015:41).

The emergence of insurgency has introduced a terrorist dimension, hitherto unknown, into the criminal space in Nigeria. Series of bombings have been carried out by the terrorists, as well as taking hostage of innocent citizens. Even the United Nations Building in Abuja was not spared in the bombing spree. In rich as well as poor countries, terrorism exerts a heavy toll on national economies. It is inevitable that the economic impact of terrorism would be more felt in unsophisticated mono-cultural low-income economies than they would be felt in highly advanced, diversified industrial economies (Adebayo, 2014:481). Therefore, the continued rise in insecurity in the country, if not checked, may result in greater investor apathy for the country and resulting in low inflow of Foreign Direct Investment (FDI), and would make institutional investors look for other stable economies to invest their money. When people feel insecure in a country, their appetite to invest, to buy or rent from the product of investment reduces; and that is why all over the world, any country that radiates an environment of insecurity naturally repels investment initiatives from both the international community and its own local investors (Awojobi, 2014:144). Hence, crime is a threat to the economic, political and social security of a nation and a major factor associated with underdevelopment; because it discourages both local and foreign investments, reduces the quality of life, destroys human and social capital, damages relationship between citizens and the states, thus undermining democracy, rule of law and the ability of the country to promote development (Adebayo, 2013b). Terrorism has created widespread insecurity across northern Nigeria, increased tensions amongvarious ethnic communities, interrupted development activities, frightened off investors, and generated concerns among Nigeria's northern neighbours. Terrorists have been responsible for near daily attacks in Borno and Yobe States and behind the January 20th attack in Kano that killed almost 200 people and three major attacks in Abuja, including the bombing of the United Nations headquarters in August 2012. Terrorist's 
attacks on churches and mosques are particularly disturbing because they are intended to inflame religious tensions and upset the nation's social cohesion (Eme\&Ibietan, 2012). In recent times, studies have emerged to address the problem of terrorism which have assumed a monstrous dimension in Nigeria both in the frequency of occurrence and the sophistication in character, while the existing studies focused on the occurrence of terrorism and its effects on national security and development in the North-Eastern part of Nigeria, empirical studies about the impact of terrorism on peace and national development in the South-South geopolitical zone is relatively lacking. Hence, this research work was aimed at examining the impact of terrorism on peace and national development in Nigeria via the survey of respondents in the South-South geopolitical zone of Nigeria.

\section{Statement of the Problem}

Terrorism became a frequently used term in Nigeria since 2009 when insurgency started afterthe death of Mohammed Yusuf, a Boko Haram leader. from that time, the activities of the sect have continued unabated despite the effort of government to curtail the heinous crime of the sect. The activities of terrorists have caused the country the lives of over 10,000 people(Udu and Edeh 2019). Most of the operations of terrorists are concentrated in the North East of Nigeria. Terrorists in Nigeria have used kidnapping and raping of women as a tool of war (Awojobi, 2014). Over the last decade, Nigeria had experienced tremendous security challenges ranging from armed robbery, ethnic conflicts across the different geopolitical zones, kidnappings to terrorism and insurgency in the South-South and North-East. Since 1999, the trend in security challenges has attained a bewildering dimension. Terrorism according to Mbaegbu (2017:234), “creates significant problems in failed states like Nigeria, impedes the development, and creates new threats to international security". Nigeria is currently enmeshed in a myriad of security challenges that pose a threat to security and national development. Terrorism increases "the cost of doing business for the private sector and providing public services. Resources that would have been invested in increasing output, fund education, health and other welfare programmes are diverted to crime control and prevention" (Adebayo, 2013).Awojobi (2014), Akinyetun (2017), Adelaja, Labo and Penar (2018) and Udu and Edeh (2019) affirm that a situation where the funds allocated to security alone is almost equal to funds allocated to education, health and critical infrastructure combined in a fiscal year, as is the case with Nigeria is detrimental to peace and national development. .

In recent times, studies have emerged to address the problem of terrorism which has assumed a monstrous dimension in Nigeria both in the frequency of occurrence and the sophistication in character. While the existing studies focused on the occurrence of terrorism and its effects on national security and development in the North-Eastern part of Nigeria, empirical studies about the impact of terrorism on peace and national development in Nigeria is relatively lacking. Hence, this research work was aimed at examining the impact of terrorism on peace and national development in Nigeria via the survey of respondents in the South-South geopolitical zone of Nigeria.

\section{Research objectives}


The general research objective was to evaluate the effects of terrorism on peace and national development in Nigeria. The following were the specific objectives:

To examine the relationship between terrorism and peace in Nigeria.

To examine the relationship between terrorism and national development in Nigeria.

To examine the extent to which terrorism impact on peace in Nigeria.

To examine the extent to which terrorism impact on national development in Nigeria.

Research Hypothesis

The following hypotheses were tested in this study:

H1: $\quad$ There will be no significant relationship between terrorism and peace in Nigeria.

H2: There will be no significant relationship between terrorism and national development in Nigeria.

H3: $\quad$ Terrorism does not have a significant effect on peace in Nigeria.

H4: Terrorism does not have a significant effect on national development in Nigeria.

\section{Conceptual Clarification}

Given the nature of this research, it is significant to outline the essential concepts employed in the study.

\section{The Concept of Terrorism}

Despite decades of effort, with even greater focus after September 11 attack on the world trade centre in the United States in 2001, attempts to develop a generally accepted legal concept of terrorism have failed (Golder \&Williams, 2004: 270). The failure is made possible because of the individual variability both in kinds of conflicts and in their methods of operation. Conflicts occur under very many different circumstances and take a bewildering variety of forms (Golder \& Williams, 2004). However, Burton (1979: 11), defined terrorism as"a range of social and political problems whose behavioural scope is boundless and includes behaviour that appears to be abnormal". Burton (1979) when further to state that it's an unconventional political violence or the threat of political violence meant to have an impact on both the immediate victims and the audience that is carried out by non-state actors and, or clandestine state agents. Burton's clarification points clearly in the direction that 'non-state-actors and/or clandestine state agents' use illegal explosive devices to perpetrate 'unconventional political violence' meant to create 'impact on both the immediate victims and the audience.' In line with this argument, Rapoport (2017) asserts that terrorism is a global phenomenon involving the use of terror for a wide range of purposes.

\section{Causes of Terrorism in Nigeria}

Studies have examined the root causes of terrorism in Nigeria and these causes can be grouped as social, youth unemployment, economic, religious, political, corruption, foreign link or connection, poverty and ethnic politics. The above root causes of terrorism were discussed in this subheading. Poverty and unemployment have been identified by some studies as common causes of terrorism.(Shehu, 2015; Adesoji, Abdullahi, \&Penar 2018;Kamta, Azadi\&Scheffran, 2020). However, several studies have found no link between poverty, unemployment and terrorism(Shehu, 2015; Adesoji, Abdullahi, \&Penar 
2018). The general belief of security and intelligence community is that people who are economically deprived are more likely to resort to violence as a way to express their grievances. That is poverty and unemployment create terrorism. The theory of relative deprivation explains that when people feel deprived of something they are expected to have, they become discontent, hence could use violence to express their grievances. Although, it is argued that poor economic conditions such as lack of employment opportunities and poverty create the condition for people to join terrorist organizations. A study by Kavanagh (2013) found out that poor but highly educated people were the ones likely to participate in terrorism (Adesoji, Abdullahi, \&Penar 2018: 38).In a research carried out by Shehu (2015) he found evidence that the greater the income inequality there is in a country, the greater the incidence of domestic terrorist attacks. Krieger \&Meierrieks(2014) cited in (Shehu, 2015) sampled 114 countries between 1985 and 2012, both found out that income inequality is correlated with terrorism. But, other empirical studies have found no support to suggest that the income distribution of a country is related to terrorism. In northern Nigeria, there is the common perception that violent extremism is entrenched in the socioeconomic problems of the country. For example, Ayegba (2015) argued that poverty and unemployment are the driving forces behind the insurgency in Nigeria. Further in the study, Ayegba(2015) claimed that the high rate of youth unemployment has resulted in poverty and insecurity in the country. Adebayo (2014:480) argued that, "socio-economic indices such as poverty, unemployment, inequality, economic underdevelopment, low education, brought about the emergence and persistence of Boko Haram terrorism in Nigeria.” These assertions suggest that the pervasive poverty and unemployment in northern Nigeria create the condition for young people to be manipulated and recruited by Boko Haram. Similarly, Kamta, Azadi\&Scheffran (2020) are of the view that though, poverty is the reason why youths become terrorist in Nigeria, it is not enough factors, and rather the neglect of the socioeconomic region of the North is the key cause for the cause of terrorism in the country. Although, some studies have found no link between poverty and terrorism, the vicious cycle of poverty and unemployment make it easy for people to become prey for Boko Haram recruitment.

It is common belief that religious tension and religious fundamentalism is another cause of terrorism in Nigeria. With respect to Boko Haram, religion plays a vital role in their discourse. The group holds extreme religious ideology, which they use as the basis to commit their heinous crimes. Omale (2013:98) argued that the rise of Boko Haram is embedded in Islamic fundamentalism, which they use to justify their actions. According to Omale (2013:98) the group aims to promote Sharia law and create an Islamic state in Northern Nigeria. As a result, it has waged war on any group or western idea, which they believe is against Islam. This has created the notion that terrorism is linked to religious fundamentalism. In the study, why do people join Boko Haram? Onuoha (2014) found out that, "ignorance of religious teaching is the leading factor influencing the adoption of extreme religious views, especially among youths" in all the northern states surveyed. Onuoha (2014) added that, religious and ethnic tensions are found to cause terrorism. Historically, Nigeria has experienced recurrent ethno-religious clashes. Although, it is hard to claim that the emergence of Boko Haram is related to religious or ethnic conflict, some studies have found a positive relationship between religious, ethnic tensions and terrorism. This implies that societies experiencing religious tension can become a breeding ground for terrorists to operate (Akinyetun, 2017). 
With respect to the political root causes of terrorism, several studies have indicated that the lack of civil liberties, corruption, weak political institutions, political instability, weak government, high level of repression, civil wars can foment the incidence of terrorism. In addition, a study by Adesoji, Labo \& Penar (2018) shows that societies with large complex multiparty systems are more prone to terrorist incidence than those with few homogeneous systems (Adesoji, et al. 2018). Also, democratic countries, which are assumed to be in a better position to stop terrorist attacks, are more prone to terrorist attacks than autocratic countries. Krieger \&Meierrieks cited in (Udama, 2013: 112) argued that democratic countries are prone to terrorist attacks due to the promotion of democratic ideals like respect for civil liberties and free press, which open doors for terrorists to operate and also hinder counter terrorism measures. On domestic terrorism in North-East Nigeria, some studies blamed the emergence of Boko Haram on the country's elite politics. Kamta et al., (2020) argued that "Boko Haram is a political construct, sponsored by politicians." According to Udama, 2013:113) Boko Haram emerged from the struggle among northern and southern political elite to gain control of state political power, especially after the death of President Yar'Adua. The re-election of Jonathan in 2011 led to the use of Boko Haram as an instrument of destruction by northern political elite. However, these claims cannot fully explain the emergence of Boko Haram, since other political and social phenomenon could contribute to the rise of the group. For instance, some scholars have argued that emergence of the group could be linked to bad governance, corruption and economic deprivation in northern Nigeria, which has fostered the rise of radical extremist groups (Udama, 2013).

In Nigeria, the vicious cycle of poverty that happened is due to youth's unemployment which approximately over 64 million youths' are unemployed and 1.6 million are under employed. Unemployment causes social frustration, dejection, dependency on family and desperation that forced youths to embark on bad social attitudes of violent crimes, assault, burglary, extortion, kidnapping, militancy, destruction of lives and more recently is terrorism (Kamta, et al., 2018). According to Awogbenle (2010:833), unemployment became a great problem on Nigerian youths and juxtaposed a terrible risk and fear to the society. The economical and psychological pressure of youth unemployment is a disaster to both individual and society (Awogbenle\&Iwuamadi, 2010).

Nigeria is a country with almost 200 million people and approximately 500 ethnic groups speaking different languages and culture with about fifty percent Muslims, forty percent Christians and ten percent belonging to other religious groups (Shehu, 2015: 45). The country has abundant of human and natural resources and number six in terms of oil wealth global ranking, and an OPEC member. Despite all these endowment of human and natural resources, Nigeria has currently been ranked as 161 out of 189 poor economies by Human Development Index (Oluwabunmi, 2020). According to International Fund for Agricultural Development (IFAD, 2007), that despite the Nigerian resources of human and natural endowment as well as oil wealth, the country ranked as one of the poorest countries in the global ranking with 70 percent of its population as poor and 30 percent in absolute poverty (Kester, 2012). This problem of poverty caused many of Nigerian citizens to engage in social violence. According to Shettima (2009), the Almajiri (child pupil) scattered all over the streets with calabash in their hands for alms begging looking very dirty, hungry, and thirsty and in traffic hazards. In northern Nigeria, the Almajiris were seriously neglected and this made them willingly join Boko Haram and engage in violent 
aggression and other social and criminal activities of Boko Haram. As reported in Saturday Tribune of 14th July, 2012, a fifteen year suicide-bomber (an Almajiri) attacked the Maiduguri Central Mosque and killed ten innocent Nigerians with the narrow escape of the Emir (Shehu) of Borno and the Borno State Deputy Speaker (Sampon, 2011:4).

The high number of poverty is caused by high level of corruption in Nigeria as it was ranked among the most corrupt country in the world in 2001 (the Transparency International Corruption Index, 2001). According to Adetoro 2012 cited in (Suleiman, 2011), the majority of Nigerian agencies and ministries were found guilty of corruption and the police was ranked as the most corrupt agency among them which gives chance to Boko Haram insurgency to expand its militant activities. Utebor, (2012) reported that illegal public executions of Boko Haram sects and hundreds of extra-judicial killings by Nigerian police as depicted on the Al-Jazeera TV, were allowed to "go un-investigated and unpunished. Due to high number of police corruption and injustice, Utebor (2012) stated that the former president of Nigeria, Olusegun Obasanjo categorizedthe National Assembly political office holders as 'rogues and armed robbers' due to their oil scandal in Nigeria. This confirms the allegation of the Central Bank of Nigerian Governor against the Nigerian political office holders (that are less than one percent of the population) for sharing more than twenty five percent of the national budgets to themselves (Sanusi, 2010).

Again, Boko Haram is a representative of the movement of Islamic Jihad Propagation in northern Nigeria, but it is being questioned that there is a signal of foreign intervention or influence from other foreign countries or organization that finance it with money and weapons to discharge its insurgency accordingly and continue with its daily violent activities, kidnapping, raping, assault, burglary, extension, terrorism, militancy and other social violence. According to United Nations reports (2011),Boko Haram has a connection with Al-Qaeda Islamic Movement (AQIM) in the Maghreb region in order to expand its mission (Nossiter, 2012). Also, the link between the Boko Haram, AQIM and Somalia's Al- Shabaab are considered the similarities of their violent activities of suicide bombing attacks and contacting the outside terrorists with an intention to relate with one another in order to threaten the United Nations and its allies due to the suicide bombing of United Nations House in Nigeria in August, 2011 by Boko Haram (Suleiman, 2011).

\section{Youth and Terrorism in Nigeria}

In Nigeria, over sixty-four million youths are not gainfully employed and over one million are said to be underemployed (Adebayo, 2014: 482). Despite the above figure, unemployment rate has continued to be on the rise in spite of the natural and human resources Nigeria is blessed with. Lingering youth unemployment is evident in Nigeria (Adebayo, 2013a).One of the major reasons why terrorism has continued to strive in Nigeria is as a result of youth's unemployment which has brought about poverty in the country. This has made recruiting young boys and girls into becoming terrorists very easy as most youths see it as a source of income to take care of their family. Unemployment has become a major problem tormenting the lives of the Nigerian youths and this poses a serious security risk to the country. The phenomenon of youth unemployment is devastating to both the individual and the society as a whole both psychologically and economically.Unemployment causes frustration, dejection, desperation and dependency on family members and friends who also have their own problems to contend with. This precarious situation has left the youths in a vicious cycle of poverty that daily erodes their 
confidence and bright future (Adebayo, 2013a) making them prone to becoming terrorists or involving themselves in crimes thereby increasing insecurity in the country. In 2013, the United States Institute forPeace carried out a study in Nigeria on the brain behind easy radicalization on youths despite all the efforts and policies of government to put an end to insurgency in the country. The states used for this study were Borno, Sokoto, Yobe, Kaduna, Gombe, and Kano. Some of the variancesare because mobilization can be very context-specific. Personal involvement in terrorism among its membership also varies widely. Some are foot soldiers or the builders of the bomb. Others are criminals, or strategists (Onuoha, 2014). Nonetheless, the study discovered social, religious, economic factors to be responsible for radicalization of youths into becoming terrorist in Nigeria. Though, economic factor was the core reason why youths have links to terrorism in the country (Onuoha, 2014). Ucha (2015) puts it that joblessness is a major factor contributing to poverty in Nigeria. When citizens are not gainfully employed, their source of livelihood reduces overtime. When the cost of living goes up, the standard of living falls. In Nigeria, millions of young people are out of jobs and this has made them get involved in crimes like internet scam, terrorism and kidnapping etc...The situation of povertyand unemployment in Nigeria can be appropriately described using the epitaph of Onimode's paradox of wealth and mass poverty. Nothing explains the paradox of poverty in the midst of plenty in Nigeria than what Onimode cited in (Usman, 2015:96). Usman (2015:96) noted that "in contrast to the cynicism of the vicious circle of poverty theorist that a country is poor because it is poor, Africa and especially in Nigeria is poor not because it is not endowed with resources but due to poor management of these resources by its political leaders. Put it differently, the abundant resources, human and materials that the country is blessed with ironically underpin the basis of profound misery of the vast majority of the people (Ucha, 2015). For a country like Nigeria that parades high deposits of material and mineral resources which range from its famous oil and natural gas to substantial reserves of coal, iron ore, zinc, tin, limestone, lead and niobium and many untapped ones including a significant proportion of arable land, approximately $90 \%$, has no business to populate poor citizens. Coincidentally, the country's vast resource complements its large population (Adebayo, 2014).

Nigeria has a young population, with 42.4 percent aged between 0 to 14 years and just around 5 percent over the age of 65. Despite this, majority of them remain either unemployed or underemployed (Ajaegbu, 2012). Thus, Awogbenie\&Iwuamadi (2010) contended that during this period, overall unemployment experienced quantum leap from 12.3 percent of labour force to 23.9percent. However, Usman (2015:96) noted that the situation became more critical in 2011 when Nigerians aged 15 to 24 (37.7\%) and those between ages 25 to 44 (22.4\%) were willing to work but are not gainfully employed. According to Usman (2015:96) in $201146.5 \%$ of youths who are unemployed are educated male youths who are to be breadwinners of their families. These groups of youths can easily be lured into becoming terrorists. The magnitude and expansion of poverty in Nigeria and the threat it poses makes it one of the biggest challenges in the nation today (Adawo, 2012:389). Ajaegbu (2012:315) who argued that 'violent crimes such as armed robbery, kidnapping and terrorism are the most inhumane crimes that continue to plague Nigeria. Lately, kidnappings for ransom and terrorism have taken centre stage leading to bloodshed and economic setbacks. The reasons for these are not farfetched as studies have linked rising youth joblessness to the increase in violent crimes. Furthermore, Ajufo (2013:308) 
corroborated the above assertion when she said "unemployment has become a major problem bedevilling the lives of Nigerian youths, causing increased militancy, terrorism and so on. The high rate of unemployment among youths in the country has contributed to the high rate of poverty and insecurity in Nigeria. Ironically, northern Nigeria has held on to power for substantial period since the country gained independence in 1960, but continues to occupy the lower level of human development index when compared to southern Nigeria, as regional poverty is always widespread and even more severe there". Consequently, it is convenient to say that when a particular segment of a country's population especially the productive youths has no job and decent living, the tendency is that they become easy targets for terrorism and other evil vices in the society. This clearly expresses the current situation the country is facing. In a country like Nigeria where those who looted the commonwealth of the people are flaunting them freely in the face of extreme poverty and hunger, temptation to extremism and violent behaviour naturally become irresistible and attractive to those without any form of consolation. In the writing of Pizza \& Hippel (2012:34) "the notion that poverty is a root cause of terrorist violence is widely asserted. This assertion is not surprising considering how well it fits with basic liberal economic theory, which pre-supposes that individuals are motivated primarily by material wellbeing. Those who have opportunities to sustain and better themselves will likely accept the system in which they live and behave peacefully. By contrast, those confronting socio-economic distress and deprivation are more likely to be drawn to radical and possibly violent movements, including terrorist movements."

The above quotation is supported by several submissions of those who believe that extremism and security challenges posed to 21st century civilization is reinforced by poverty, unemployment, illiteracy and ignorance (Pizza \& Hippel 2012:34).For instance, while commenting on the rapidity with which terrorism was taking on America and the rest of the global community in 1994, Bill Clinton, the then American president said that "the forces of terror and extremism... feed on disillusionment, on poverty, on despair." Thus, in his view, containing and putting an end to terrorism is to spread prosperity and security to all.” Again, the al-Qaeda-led attacks on the World Trade Centre and the Pentagon on September 11, 2001, further bolstered the poverty terrorism thesis. The advent of democratic rule in 1999 raised hopes that the long years of suffering, poverty, inequality and alienation of the mass of people to era of prosperity, leadership at all levels of governance failed the people. Their expectations and hopes were dampened as their situations and conditions deteriorated and exacerbated with increased unemployment rate, illiteracy, low income and hunger. This led to the youths forming several ethnic based armed groups and sporadic search for tribal identity. This led to militancy in the SouthSouth geopolitical zone, kidnapping and robbery in the East and West, and series of religious violence including the prevailing extremism vis-a-vis terrorism in the North.

The rate of poverty in Nigeria has worsened since the late 1990s, to the extent that the country is now considered as one of the twenty poorest countries of the world (Adebayo, 2013c). The frustration and desperation that daily torment the unemployed creates a fertile ground for crime to thrive. In recent times, there have been notable adverse social, economic and political developments in Nigeria, a consequence of youth unemployment and underemployment, particularly exemplified by increasing militancy, violent crimes, kidnapping, restiveness and political instability (Ajufo, 2013). The scariest undertone of Nigeria's socio-economic underachievement, by far, is the steady rise in 
youth crime, nurtured in a climate of increasing national income and the simultaneous failure of employment generation and poverty alleviation programmes. Armed insurgency and terrorism culminating in wanton destruction of lives and property by Boko Haram extremists in the northern part of the country are now competing for space in international headlines. The season of discontent has special ramifications for a nation with unemployed millions, and the net effect has been a tragic precipitation of violent crimes, assault, burglary, extortion and kidnapping etc. Decades of social and political turmoil have helped turn the strategically located African nation into an established junction for international drug smugglers (Okafor, 2011). Other highlights of Nigeria's prolific crime syndicates are economic fraud usually in the form of innovative internet scams, money laundering and racketeering (Ajufo, 2013). Furthermore, Adejumola\&Tayo-Olajubulu (2009) contended that unemployment has been identified as the major cause of social vices like terrorism, armed robbery, destitution, prostitution, political thuggery, and kidnapping. What holds true for Nigeria and most other nations of equivalent human development indicators is the fact that crime is often a means of survival. The youths are one of the greatest assets a nation could possibly possess. The National Youth Development Policy (2001) asserts that the youths are the foundation of a society; their energies, inventiveness, character and orientation define the pattern of development and security of a nation. Through their creative talents and labour power, a nation makes giant strides. The youths are a particular segment of the national population that is sensitive, energetic, active, and the most productive phase of life of citizens. The youths are also the most volatile when their energies are misdirected or channelled into wrong endeavours. Consequently, youth unemployment poses a great threat to the country's stability and development, and if not checkmated on time, it may lead to disastrous consequences for the nation. Desperation can drive the unemployed youths into living outside the law in order to survive and as a means of expressing dissatisfaction at the apparent neglect of their very existence. This situation has afforded the Boko Haram terrorist sect the luxury of easy recruitment of young people into their fold.

\section{Terrorism and Peace}

Over the years, the pursuit of political objective via sporadic terrorism and violence has frustrated the amount of work put into domestic and global maintenance of peace and security. The attack on government by terrorists in the twenty first century as backed up by the advancement in sophisticated technology has weaken many governments all over the globe.Terrorists activities are transnational and have inevitably crossed porous borders. This has made it difficult for governments to control security systems since technology considers no border. The concept of terrorism is a subject of intense controversy within the United Nations (UN) and other peace fostering organizations. There is no consensus definition of terrorism, thus, terrorists possess a great merit of that weakness to pursue their clandestine political objectives. Humphries (2002:732), defines terrorism as, the "use of violence, sometimes indiscriminately against persons and property for nominal purpose of making a political statement.” This entails scars, death and loss of lives and properties, following the promiscuous act of terror.The nightmare on the soil of the United States of America (USA) precisely the World Trade Centre (WTC) and the Pentagon in New York City (NYC) on 11 September 2001(9/11), Mumbai attacks in 2008, Bali bombing, Istanbul bombings, Chechnya, London bombings, Madrid, Kosovo, Montenegro, Israel, East 
Timor, Northern Island, Kashmir and the Abuja December bombing by Boko Haram. With this going rate of terror and horror, there is a call for utilitarian approach to curb insurgency in achieving peace. However peace itself has become very essential in today's world.

The word 'peace' in the English language is derived from the Latin 'pax'. Peace in the Roman Empire meant a cessation in fighting as well as rule over subject races. A modern equivalent is found in definitions of peace through deterrence. This definition describes peace in terms of what it is not, rather than what it is. The term 'peace' does not merely imply the absence of overt violence (sometimes referred to as 'negative peace'). It also encompasses the presence of social, economic and political justice, which is essential to the notion of 'positive peace' (Hicks, 1985).Peace is a relationship variable, not a trait. Peace exists among individuals, groups, and nations; it is not a trait or a predisposition in an individual, group, or nation.Peace is dynamic, not a static process. The level of peace constantly increases or decreases with the actions of each relevant party.Peace is an active process, not a passive state. Passive coexistence is not a viable path to peace. Building and maintaining peace takes active involvement.Peace is hard to build and easy to destroy. It may take years to build up a stable peace, then one act can destroy it (terrorism). The relationship between the concept of terrorism and peace are numerous following their frequent interactive nature as one seems to influence the other. According to Tichaona (2013: 695) Terrorists activities weaken states ability to provide peace to its citizens. Women; children and men have all suffered the consequences of terrorism.Terrorism disrupts livelihoods, increases violence and fear, affects production in all sectors of economy, destroys infrastructure and has resulted in bloodshed. In all cases of terrorist attacks, it has disrupted normal life, stalled production in the economy and international effort to provide peace and security. This justifies the importance of providing an analysis on the effects of terrorism in maintaining international peace and security (Tichaona, 2013).

Terrorism is a menace, the magnitude of destruction, loss of life, injuries and disabilities have all made mankind fail to find comfort in their governments as citizens are left vulnerable to indiscriminate attacks of terrorists. The effects of terrorism range from short, medium and even long term. Peace happens to breed and yield more economic benefits than in an atmosphere of terror. Abadie (2007:7) states that terrorism "reduces capital stock of a country, threatens higher level of uncertainty, increases counter terrorism expenditure, and drawing resources from productive sectors for use in security and affects specific industries like tourism.” Also on the global economy in 2019 \$14.5 trillion in purchasing power parity (PPP) terms. This figure is equivalent to 10.6 per cent of the world's economic activity (gross world product) or \$1,909 per person. The economic impact of terror improved by 0.2 per cent from 2018 to 2019. The biggest improvement was in armed conflict, which decreased by 29 per cent to $\$ 521$ billion, owing to a fall in the intensity of conflict in the Middle-East and North Africa. There was also a substantial reduction in the economic impact of terrorism, which fell by 48 per cent from 2018 to 2019. Violence continues to have a significant impact on economic performance around the globe. In the ten countries most affected by violence, the average economic impact of violence was equivalent to 41 per cent of GDP on average, compared to under 4 per cent in the countries least affected by violence. Syria, South Sudan, Afghanistan and Venezuela incurred the largest proportional economic cost of violence in 2019, equivalent to 60, 57, 51 and 48 per cent of GDP, respectively. 
However, terrorism set to destroy what peace has built over time. This notwithstanding, the occurrence of terror calls for peace and its value, while peace builds whatever horror, terror has caused or would have caused. Gasper (2008:12) states that "human security redirects attention in the discussions of security from the national or state level to human beings as the potential victims; beyond physical violence as the only relevant threat; and beyond physical harm as the only relevant damage.” Human security includes economic security, food security, health security, environmental security, personal security, community security and political security. As such the masses will revolt and use violence on their government. This also breeds an environment for the emergence of terrorists thereby having a negative effect on peace.

\section{Terrorism and National Development}

Different scholars from the field of social sciences, and humanities have all shared their views on terrorism and national development. According to the United States Department of Defense (2000), terrorism is "the calculated use of unlawful violence or threat of unlawful violence to inculcate fear; intended to coerce or to intimidate governments or societies in the pursuit of goals that are generally political, religious or ideological”. Inherent in this definition are the three key elements of violence, fear, and intimidation. All three elements conjoin to instigate terror in the victims or those at the receiving end. The American Federal Bureau of Investigation (FBI) (2002), on its part, defines terrorism as "the unlawful use of force and violence against persons or property to intimidate or coerce a government, the civilian population, or any segment thereof, in furtherance of political or social objectives". The U.S. State Department, on the other hand, understands it as the deployment of "premeditated politically-motivated violence perpetrated against noncombatant targets by subnational groups or clandestine agents, usually intended to influence an audience. Quoted in Omotola (2010), The African Union (AU) sees terrorism as "any act which is a violation of the criminal laws of a state party and which may endanger the life, physical integrity or freedom of, or cause serious injury or death to, any person, any member or group of persons or causes or may cause damage to public or private property, natural resources, environmental or cultural heritage". Terrorism has been described as the "criminal acts intended or calculated to provoke a state of terror in the general public, a group of persons or particular persons for political purposes that are in any circumstance unjustifiable, whatever the considerations of a political, philosophical, ideological, racial, ethnic, religious or any other nature that may be invoked to justify them” (UN, 1994).

Terrorism has always had huge financial implications and burden to the affected country. In Nigeria, terrorism has had negative effects on the overall national development of the country. For example, it has been estimated that the city of New York alone lost US $\$ 21$ billion as a result of the 9/11 terrorist attacks. With the establishment of the Homeland Security, the US Government now has to spend a whopping US\$500 billion on security alone. Globally, it has also been calculated that world GDP decreased by a whopping US\$3.6 trillion in 2002 as a direct and indirect consequence of terrorist activities in 2001. This amount can be put in perspective when we realize it amounts to a third of the GDP of the United States and exceeds the combined GDP of Argentina, Italy and Britain. Another area of economic cost relates to the impact of terrorism on international trade supply chains, that is, the sequence of steps that global suppliers of goods take to 
get products from one area to another (Mailafia, 2013). In a similar way, the budget of N921.91 billion earmarked to combat terrorism in Nigeria in the year 2012 alone, could have been deployed to national development programmes that the nation desperately need. According to (Ekundayo, 2015:11) national development is the "overall development or a collective socioeconomic, political and technological advancement of a country or nation. This is best achieved through development planning which can be described as the country's collection of strategies, policies, plans, programmes and projects and others, mapped out by the government.” In the same vein, Adebayo (2013: 353) defines development, "as an important mode of production in modern society and the key in classifying countries as developed, underdeveloped, developing or emerging economies based on their level of industrialization'”. Imhonopi (2004) argues that national development in Nigeria over the years is low because of factors such as poor infrastructural development, low level of technology, inadequate capital, poor state of the agricultural sector, low manpower development, poor planning and implementation, high degree of dependence on foreign raw materials, political instability, unfavourable government policies, entrenched official corruption, tribalism and nepotism. While these factors are true, another challenge that may further set the country back in achieving rapid development is the deepening terrorist activities in Nigeria especially as triggered in the South-South geopolitical zone and Boko Haram terror groups in the northern part of the country. All these over the years have affected national development negatively in Nigeria (Imhonopi, 2004).

Apart from the economic and monetary costs associated with terrorism, there are also social and psychological costs. Terrorism erodes inter-communal trust and destroys the reservoir of social capital that is so vital to building harmonious societies and bringing together community energies for national development. The attendant proliferation of small arms and the militarization of society results in a vicious cycle of violence which hampers national cohesion and stability. WhileLawal\&Oluwatoyin (2011) see national development as the overall development, socio-economic, political as well as religious advancement of a country. The long term impact of such violence on cities and regions is best exemplified by the penury that has affected Kaduna and Jos. Kaduna used to be one of the most prosperous cities in Nigeria. The Kaduna and Jos violence are as a result of religious conflicts which Lawal\&Oluwatoyin (2011) view to be against the religious advancement of Nigeria. It was in many ways the industrial hub of the North, a cosmopolitan city with over a dozen textile firms and prosperous trading companies. The Kaduna of today is a tragically divided city in which Muslims live predominantly in the North and Christians predominantly in theSouth. All the textiles companies have shut down and most investors have packed up their businesses. The Jos Plateau is following a similar trend, as it loses its cosmopolitanism and local economies are destroyed. The tragedy is that the collapse of local economies and the erosion of social capital reinforce a downward spiral of further impoverishment, which in itself sows the seeds of further conflict and under development.In the South-South geopolitical zone, the activities of the militants have in different ways affected national development in Nigeria. Bombings of pipelines and closing down crude oil productions in the country have negative effects on the overall development of the country (Eme\&Ibietan, 2012). 


\section{Theoretical Framework}

This study adopted the frustration and aggression theory. The frustrationaggression theory is associated with the works of Dollard, Doob, Miller, Mowrer \& Sears (1939). The core assumptionof this theory is that "aggression is always a consequence of frustration" (1939:1). The authors argued that individuals are motivated to achieve life ambitions and fulfil destiny, but when these expectations are thwarted, frustration sets in. In their line of thought, the occurrence of aggressive behaviour presupposes the existence of frustration; and that "the existence of frustration always leads to some form of aggression" (Dollard et al., 1939: 1). However, it is important to note that the existence of frustration does not always lead to aggression, given that frustration may have other consequences other than aggression. The concept of Frustration-Aggression as a way to terrorism brings to mind that frustration and aggression are vice versa. Social disciplines assume it as a cause of social upsets derived out of governments' alienating policies (Berkowiz, 1989). According to this theory, the common people not only are deprived of their rights in the society but the means of strengtheningtheir rights are also blocked from them, hence they are unable to react to those deprivations. This blocking occurs by the mighty in the society or by the established system which dominates the entire circumstances. In this case, the deprived, marginalized and frustrated individuals or groups attempt to express their frustration and annoyance. In the words of Miller (1939), this frustration produces a variety of retaliatory actions such asthe diffusion of frustration into aggression and the terrorism does not express only an individual's psychological state but it necessarily means to express about the prevailing phenomenon in the whole society or country. Furthermore, it might be caused by internal or external factors. Internally, the basic reasons for this state are mal-governance, political destabilization which further creates economic inequality, injustice, un-employment, while the external factors can be exemplified through direct or indirect occupation (Berkowitz, 1989). Thus, when the frustrated people are unable to fight against the mighty powers they react violently against state's writ or external occupation. Insurgency, revolutionary and sub-revolutionary terrorism and international terrorism are examples of this reaction. The main difference between the crime and terrorism as a resultant factor of aggression is that crime is a disorganized act committed by an individual or group of individuals for materialistic interests, while terrorism is a systemic action, committed by group as a result of frustration (Tedeschi\&Felson, 1994).

Terrorism can be driven by frustration, oppression, exploitation and social inequalities. The use of terror and violence by terrorist groups is aimed to intimidate or coerce government and the public in order to promote political, social ideological and religious or philosophical objectives. Looking at the militants attacks in the South-South geopolitical zone , one can affirm that the astronomically relative deprivation is in terms of the economic deprivation which has brought aboutpoverty to the South-South geopolitical zone. The South-South geopolitical zone where most of the nation's crude oil resides, yet one of the poorest regions in the country.Majority of the youths are unemployed as their sources of livelihood have been polluted via oil spillage, lack access to quality water, no access to quality education and therefore, lacks development. These are some of the reasons that have triggered the acts of terrorism in the South-South geopolitical zone . 
In this context, aggression may develop as a consequence of having been exposed to an extremely frustrating condition sufficient enough to provoke a sense of worthiness and hopelessness. Kukah (1993) argues in favour of this position that the militants in the South-South geopolitical zone face complexities, contradictions and challenges emanating from their inability to meet up with basic human needs like foods, cloth and shelter. Soyinka (2012) agrees with this position and argues that, "economic factors, such as unemployment, wasted resources; social marginalization and massive corruption are responsible for nurturing the current season of violent discontent in the region”. It is however important to note that the existence of frustration does not always lead to aggression, given that frustration may have other consequences other than aggression.

\section{Methodology}

The study adopted across-sectional research design. This means that primary source was utilized. The researcher administered questionnaires to some notable personalities and institutions in the selected States of the South-South geopolitical zone of Nigeria.

\section{Research Instruments}

This study utilized primarydata. Primary data was sourced using the questionnaire. The questionnaire was divided into sections one and two using the five point Likert scale of close ended structured questionnaire. Section one was designed to elicit bio-data of respondents while section two was used to obtain information on the effects of terrorism on peace and national development in Nigeria.

\section{Population of the Study and Sampling Techniques}

Data was collected via a survey of 300 respondents in South-South geopolitical zone of Nigeria using purposive sampling technique.According to Obasi (2000), purposive sampling is a method in which the researcher selects people purposely for the study because of their ability to make useful data available to meet the requirements of the interrogation. The research instrument used for the study was the structured questionnaire. Out of the 300 copies of questionnaire administered, 232 were retrieved and analyzed given a response rate of $77.3 \%$. Out of the 232 respondents, 91 were female and 141 were male. The items of measurement were rated on 5-pointslikert response type scale which ranks responses on a scale of (1) strongly disagreed to (5) strongly agreed.

Table 1: Distribution of Questionnaire and Response Rate

\begin{tabular}{|c|c|c|c|c|}
\hline S/N & South - South States & $\begin{array}{c}\text { Questionnaire } \\
\text { Distributed }\end{array}$ & $\begin{array}{c}\text { Questionnaire } \\
\text { Retrieved }\end{array}$ & Percentage Retrieved \\
\hline 1 & Delta & 50 & 47 & 15.7 \\
\hline 2 & Rivers & 50 & 42 & 14 \\
\hline 3 & Bayelsa & 50 & 33 & 11 \\
\hline 4 & Edo & 50 & 36 & 12 \\
\hline 5 & Akwa Ibom & 50 & 41 & 11 \\
\hline 6 & Cross River & 50 & 33 & 77.3 \\
\hline & Total & 300 & 232 & \\
\hline
\end{tabular}




\section{Reliability and Validity of Instrument}

The reliability was established through a trial test conducted on 30 respondents in Delta State who also took part in the study. Cronbach Alpha method was used to establish the internal consistency of the instrument as shown in the table below.

Table 2: Reliability Statistics of Variable

\begin{tabular}{|c|c|c|}
\hline Scale & Number of Item & Cronbach's Alpha \\
\hline Terrorism & 12 & 0.793 \\
\hline
\end{tabular}

Source: From the Questionnaire Administered, 2020

The result yielded a coefficient of 0.793 which satisfied the general recommended level of 0.70 for the research indicators (Cronbach, 1951). Content validity was employed for this study to ensure the validity of the instruments, by subjecting it to independent assessors for cross-examination. These assessors are the main research supervisor and otherexperts who are scholars in this field from the Department of Political Science and International Relations, for their thorough and in-depth scrutiny, before it wasused. This is to ensure that this work attains a high level of accuracy and reliability in all of its content. Hence, researcher satisfied both the reliability and validity of the scale.

\section{Area of the Study}

The study focused on Delta and Edo States in the South-South geopolitical zone of Nigeria. The region is situated in the southern part of Nigeria. The geopolitical zone is made up of six states namely: Delta, Akwa-Ibom, Bayelsa, Cross River, Edo, and Rivers. Over half of the South-South is made up of a network of creeks and small islands, making it very difficult to navigate and to establish large settlements. The rural population tends to live in small scattered hamlets of 50 to 500 persons, some maintaining links with larger towns such Port Harcourt, Calabar, Warri, Yenagoa, etcetera.

\section{Method of Data Analysis}

The primary data was presented and analysed using percentages, Pearson's coefficient of correlation and linear regression analysis with the aid of Statistical Package of Social Science (SPSS) version 23.

\section{Presentation, Analysis and Interpretation of Results}

The data collected for this Study was presented and analyzed with frequency distribution and percentages while the hypotheses formulated were tested using Pearson's coefficient of correlation and linear regression analysis. Of the three hundred (300) copies of questionnaire administered, two hundred and thirty two questionnaires properly filled were retrieved and used for the study. The questionnaire administered consists of respondent's personal data and the items that addressed the purpose of the study.

Table 3 Sex of Respondents

\begin{tabular}{|c|c|c|}
\hline Sex & Frequency & Percentage \\
\hline Male & 141 & 60.8 \\
\hline Female & 91 & 39.2 \\
\hline Total & 232 & 100.00 \\
\hline
\end{tabular}


Source: Field work, 2021

Table 1 show that $60.8 \%$ of the respondents were male, while $39.2 \%$ were female

Table 4 Marital Status of Respondents

\begin{tabular}{|c|c|c|}
\hline Marital Status of Respondents & Frequency & Percentage \\
\hline Single & 87 & 37.5 \\
\hline Married & 132 & 56.9 \\
\hline Divorced & 13 & 5.6 \\
\hline Total & 232 & 100.00 \\
\hline
\end{tabular}

Source: Field work, 2020

Table 2 the distribution of marital status of respondents as presented by the above table shows more married respondents (56.9\%) as against the single which accounted for (37.5\%) and little percentage of divorced (5.6\%).

Table 5 Age Distribution Respondents

\begin{tabular}{|c|c|c|}
\hline Age & Frequency & Percentage \\
\hline $18-30$ yrs & 73 & 31.5 \\
\hline $31-40$ yrs & 97 & 41.8 \\
\hline 41 and above & 62 & 26.7 \\
\hline Total & 232 & 100.00 \\
\hline
\end{tabular}

Source: Field work, 2021

Table 3 shows that $31.5 \%$ of the respondents fall between the age of 18 -30 years, $41.8 \%$ fall between $31-40 y e a r s$ and $26.7 \%$ fall above 41 years, this indicates that people within the age 31-40 years have the highest population of respondents.

Table 6 Level of Education of Respondents

\begin{tabular}{|c|c|c|}
\hline Level of Education & Frequency & Percentage \\
\hline WASSCE/GCE & 51 & 22.0 \\
\hline BSc / HND & 77 & 33.2 \\
\hline Master Degree Holder & 57 & 24.6 \\
\hline Professional Certificate & 47 & 20.3 \\
\hline Total & 232 & 100.00 \\
\hline
\end{tabular}

Source: Field work, 2021

Table 4 shows that $33.2 \%$ of the respondents have attained University Level Education, 22.0\% of respondents have attained Secondary School Education, 24.6\% Masters and a small percentage of professional certificates which account for $20.3 \%$.

\section{Testing of Hypotheses}

Hypothesis 1: There is no significant relationship between terrorism and peace in Nigeria.

Table 7 Correlation Matrix

Variables
Terrorism
Peace 


\begin{tabular}{|c|c|c|c|}
\hline Terrorism & Pearson Correlation sig. (2. & 1 & $-0.369^{* *}$ \\
& tailed) & & 0.000 \\
& $\mathrm{~N}$ & 232 & 1 \\
\hline Peace & Pearson Correlation & $-0.369^{* *}$ & 232 \\
& Sig. (2-tailed) & 0.000 & 232 \\
\hline
\end{tabular}

** Correlation is significant at 0.01 levels (2-tailed)

Source: Field work, 2021

Hypothesis 1: There is no significant relationship between terrorism and peace in Nigeria. Table 5 shows negative correlation between terrorism and peace. There exists significant correlation between the independent (terrorism) and dependent (peace) variables ( $\mathrm{r}=$ $0.369, \mathrm{n}=232, \mathrm{p}<0.01$ ). The table 4.1.5 shows negative correlation between the independent (terrorism) and dependent (peace). This implies that as terrorismis increasing, peace is decreasing. Therefore, the null hypothesis was rejected.

Hypothesis 2: There is no significant relationship between terrorism and national development in Nigeria.

Table 8 Correlation Matrix

\begin{tabular}{|c|c|c|c|}
\hline Variables & Terrorism & national development \\
\hline Terrorism & Pearson Correlation sig. (2. & 1 & $-0.353^{* *}$ \\
& tailed) & & 0.000 \\
& $\mathrm{~N}$ & 232 & 232 \\
\hline national development & Pearson Correlation & $-0.353^{* *}$ & 1 \\
& Sig. (2-tailed) & 0.000 & 232 \\
\hline
\end{tabular}

** Correlation is significant at 0.01 levels (2-tailed)

Source: Field work, 2021

Table 6 shows negative correlation between terrorism and national development. There exists significant negative correlation between the independent (terrorism) and dependent (national development) variables $(\mathrm{r}=-0.353, \mathrm{n}=232, \mathrm{p}<0.01$ ). This implies that as terrorism isincreasing, national development is decreasing. Therefore, the null hypothesis is rejected.

\section{Linear Regression Analysis}

Hypothesis 3: Terrorism does not have a significant effect on peace in Nigeria

Table 9 Model Summary ${ }^{b}$

\begin{tabular}{|c|c|c|c|c|}
\hline Model & $\mathrm{R}$ & $\mathrm{R} 2$ & Adj-R2 & Std. Error of the estimate \\
\hline 1 & -0.313 & -0.255 & -0.1404 & 0.093 \\
\hline
\end{tabular}

a. Predictors (Constant), terrorism

b. Dependent variable: peace

Source: Field work, 2021

\section{Table 10 ANOVA ${ }^{a}$}




\begin{tabular}{|c|c|c|c|c|c|c|c|}
\hline \multicolumn{2}{|c|}{ Model } & $\begin{array}{c}\text { Sum of } \\
\text { square }\end{array}$ & Df & Mean & F. & Sig. & Remark \\
\hline \multirow{3}{|c|}{1} & Regression & -3.837 & 2 & -2.547 & 9.369 & $0.000^{\mathrm{b}}$ & Sig. \\
& $\begin{array}{c}\text { Residual } \\
\text { Total }\end{array}$ & -1.792 & 228 & & & & \\
\hline
\end{tabular}

a. Dependent variable: peace

b. Predictors: (constant), terrorism

Source: Field work, 2021

Hypothesis 3: Terrorism does not have a significant effect on peace in Nigeria.

The linear regression results show $\left(\mathrm{R}^{2}\right)$ value of -0.255 which revealed that terrorism independently accounted for $-25.5 \%$ of the variation in peace in Nigeria. The F. statistics of 9.369 revealed that the model is statistically significant at 0.05 significant levels. This implies that as terrorismis increasing by $1 \%$, peace is decreasing by $25.5 \%$. Therefore, the null hypothesis is rejected. Thus, terrorism has significant influence on peace in Nigeria.

Hypothesis 4: Terrorism does not have a significant effect on national development in Nigeria

Table 11 Model Summary

\begin{tabular}{|c|c|c|c|c|}
\hline Model & $\mathrm{R}$ & $\mathrm{R}^{2}$ & Adj- $^{2}$ & Std. Error of the estimate \\
\hline 1 & -0.327 & -0.187 & -0.099 & 0.015 \\
\hline
\end{tabular}

c. Predictors (Constant), terrorism

d. Dependent variable: national development

Source: Field work, 2021

Table 12 ANOVA ${ }^{\mathrm{a}}$

\begin{tabular}{|c|c|c|c|c|c|c|c|}
\hline \multicolumn{2}{|c|}{ Model } & $\begin{array}{c}\text { Sum of } \\
\text { square }\end{array}$ & Df & Mean & F. & Sig. & Remark \\
\hline \multirow{3}{|c|}{1} & Regression & -2.767 & 2 & -2.634 & 11.201 & $0.000 \mathrm{~b}$ & Sig. \\
& Residual & -1.900 & 228 & & & & \\
\hline
\end{tabular}

c. Dependent variable: national development

d. Predictors: (constant), terrorism

Source: Field work, 2021

Hypothesis 4: Terrorism does not have a significant effect on national development in Nigeria.

The linear regression results show $\left(\mathrm{R}^{2}\right)$ value of -0.187 which revealed that terrorism independently accounted for $-18.7 \%$ of the variation in national development in Nigeria. The F. statistics of 11.201 revealed that the model is statistically significant at 0.05 significant levels. This implies that as terrorismis increasing by $1 \%$, national development is decreasing by $18.7 \%$. Therefore, the null hypothesis was rejected. Thus, terrorism has significant influence on national development in Nigeria.

Table 11respondents responses on what should Government do to bring lasting Peace to the Nigeria

\begin{tabular}{|c|c|c|}
\hline No of persons & Frequency & Percentage \\
\hline
\end{tabular}




\begin{tabular}{|c|c|c|}
\hline 98 & Generate employment opportunities for the youths & 42.3 \\
\hline 53 & Provision of infrastructural facilities and genuine women empowerment & 22.8 \\
\hline 81 & Corrupt politician be punished to restore the glory of Nigeria & 34.9 \\
\hline 232 & & 100.00 \\
\hline
\end{tabular}

\section{Discussion of Findings}

The study examined the effects of terrorism on peace and national development in Nigeria. The analysis above answered the questions posed in the study and tested the hypotheses of the research. The study discovered that there is significant relationship between terrorism and peace in Nigeria. This finding, however, is in agreement with previous studies carried out by (Egugbo, 2016; Tichaona, 2013; Steward, 2012; Gasper, 2008; Aja, 2006 \& Humphries, 2002). Thus, the study revealed that terrorism exerts a negative significant effect on peace. Consequently, when terrorism increases, peace decreases. Terrorism has resulted in nightmares in the United States of America with the bombings of the World Trade Centre (WTC) and the Pentagon in New York City (NYC) on September 11, 2001 (9/11). All the cities that have experienced terrorists' attack have a decline in peace. Mumbai attack in November 2008, Istanbul bombings of 2016, London bombings of 7th July 2005 (7/7), and the Abuja 31st December 2010 bombing (Humphries 2002:732). Terrorists' activities weaken each country's ability to provide peace for its citizens. The Nigerian situation is akin to what Humphries (2002:732) describes concerning Mumbai, Chechnya, Bali, Istanbul, Madrid, Kosovo, Israel, East Timor, Kashmir, among others, where terrorism disrupts likelihoods, increases violence and fear and has resulted in bloodshed; where terrorism was initially rooted in religion but later took a political dimension. Thus, wherever and whenever terrorism is increasing, peace is decreasing among the people. The second research hypothesis which stated that there will be norelationship between terrorism and national development was rejected. The result revealed that there is significant negative relationship between terrorism and national development. This implies that as terrorism is increasing, national development is decreasing. The finding is consistent with the previous studies of (Zakaria, Jun \& Ahmed, 2019; Khan \& Yusof, 2017; Bazic, 2016;Mehmood, 2014; Mapolisa \& Matsekesta, 2013, Ocal, 2010 and Mailafia, 2013). In countries where terrorism exists, there is the tendency that development will be hampered due to the activities of terrorists. Terrorists are bound to destroy already existing growth and development. This will further make national and state government divert finances meant for national development to purchase of nuclear arsenals in battling terrorism. In the case of Nigeria, terrorism has overtime destroyed previous achievements made by successive governments and finances meant for development are now being channelled to fighting terrorism in Nigeria.

Consequently, when terrorism increases, national development decreases. Terrorism has always had huge financial implications in the countries being affected. In Nigeria, terrorism has had negative effects on the overall national development. This is similar to the experience in the United States of America where it has been estimated that the New York City (NYC) alone lost US\$21 billion as a result of the September 11, 2001 terrorist attacks. Significantly, with the establishment of the Homeland Security, the US Government today spends a huge sum of US\$500 billion on security alone. Globally, it has 
also been calculated that the world GDP (Gross Domestic Product), that is, the total market value of the goods and services produced by a country's economy during a specified period of time, decreased by a whopping US\$3.6 trillion in 2002 as a direct and indirect effect of terrorism in 2001. This monetary value can be put in perspective when we realize that it is amounts to a third of the Gross Domestic Product of the United States and also exceeds the combined Gross Domestic Product of Argentina, Italy and Britain (Mailafia, 2013).

Like in the United States where the government spends about US\$500 billion on security alone, so also in Nigeria, in the year 2012 alone, the budget of $\$ 21.91$ billion was earmarked to combat terrorism (Mailafia, 2013). This could have been deployed to national development programmes in the country. Therefore, wherever terrorism is increasing, national development is decreasing. Succinctly, the analysis on the effect of terrorism on peace in Nigeria: the study revealed that terrorism has. This is in line with previous studies by (Suror \& Guido, 2017; Cinar, 2017; Dinar, 2015). The question on the effect of terrorism on national development in Nigeria reveals that terrorism independently accounted for $18.7 \%$ of the variation in national development in Nigeria. This also shows that as terrorism is increasing by $1 \%$, national development is decreasing by $18.7 \%$. Thus, terrorism has great influence on national development in Nigeria. This falls in line with past studies by (AK, Aydin \& Dinar, 2015; Cinar, 2017; Guido, 2017).

\section{Conclusion}

Issues bordering on national security which embodies peace and development are very critical for the material progress of any polity. As a result of this, the study looked at the effects of terrorismon peace and national development in Nigeria using the South-South geopolitical zone as its case study. It reveals that there is a strong negative relationship between terrorism and peace. There also exists a strong negative relationship with national development in the South-South of Nigeria. Although, the study agreed that the government should come up with programmes that will provide infrastructural facilities to empower women, generate employment for the youths in Nigeria and punish corrupt politicians looting the nation's wealth, it went further to note that the heinous activities of terrorists' groupshave significant effect on peace and national development in the region and have accounted for poor living standard of people living in the region. These have the propensity to upset the gains crude oil exploration would have brought not just to the SouthSouth Geopolitical zone but to the country at large.

\section{Recommendations}

The recommendations herein are based on our findings above. The recommendations embody a tripartite dimension or implication, namely: practical, empirical and theoretical implications. These implications are enumerated below:

1) There is need for the Nigerian government to generate employment for youths who are unemployed in the country.

2) Government should come up with programmes that will provide infrastructural facilities and genuine women empowerment.

3) Corrupt politicians should be punished to serve as a lesson to others who intend to loot the nation's wealth. 
4) Government at all levels must eschew corruption in the fight against criminality, terrorism and insecurity.

5) The democratic system in place must begin to deliver the needed social goods so as to improve the standard of living of Nigerians and deliver many citizens in the SouthSouth of Nigeria from abject poverty to which they have been subjected for a long time. Therefore,

government should plug all the holes through which scarce resources are being siphoned so as to have enough resources for national development and equipping of the military to fulfil its functions of providing peace and security to Nigerians.

\section{References}

1. Abadie, A. (2007). Terrorism and world economy. John F Kennedy School of Government, Harvard University: Cambridge.

2. Abadie, A., Gardeazabal, J. (2003). The economic costs of conflict: A case study of the Basque country. American Economic Review. 93, 113-132. https://doi.org/10.1257/000282803321455188

3. Adawo, M.A. (2012). "Is Nigeria’s unemployment problem unsolvable? Research Journal of Social Science. 4:6.

4. Adebayo, A.A. (2014). Implication of Boko Haram terrorism on national development in Nigeria: A critical review. Mediterranean Journal of Social Sciences, 5(16), $480-489$. https://doi.org/10.5901/mjss.2014.v5n16p480

5. Adejumola, A.S. \&Tayo-Olajubutu, T.O. (2009). Spinning off an entrepreneur culture among Nigerian university students: Prospects and challenges. African Journal of Business Management. 3(3), 8088.

6. Adesoji, O., Abdyllahi, L., \&Penar, E. (2018). Public opinion on the root causes of terrorism and objectives of terrorists: A Boko Haram case study. Perspective on Terrorism. 12, $\quad 35-49$. https://www.jstor.org/stable/26453134

7. Ahmed, H. (2007). Strategies for accelerated rural and community development at local government level. The Nigerian Journal of Administrative Studies, 5(3): 64-77.

8. Ajagun, S. O. (2003).The significance of culture on human development in Nigeria. International Journal of Governance and Development, 1 (20):107-116.

9. Ajufo, B.I. (2013). Challenges of youth unemployment in Nigeria: Effective career guidance as a panacea. African Research Review, 7(1); 307-321. https://doi.org/10.4314/afrrev.v7i1.21

10. Akande, B.A. \&Abasilim, U. (2015). Development and its challenges in Nigeria: A theoretical discourse. Mediterranean Journal of Social Sciences. 6(6), 275-281.

11. Akinyetun, T.S. (2017). Economic consequences of terrorism in Nigeria: Implications for national development cum national security. Global Journal of Economics and Finance. 1, 15-27.

12. Amaraegbu, D.A. (2011). Violence, terrorism and security threat in Nigeria’s NigerDelta: An old problem taking a new dimension. African Journal of Political Science and international Relations. 5(4), 208-217. https://doi.org/10.5897/AJPSIR.9000141

13. Aro, O. (2013). Boko Haram insurgency in Nigeria: Its implications and way forwards toward avoidance of future insurgency. International Journal of Scientific and Research Publications. 3, 11.

14. Awogbenie, A.C. \&Iwuamadi, C.C. (2010). "Youth unemployment: Entrepreneurship development programme as an intervention mechanism. African Journal and Business Management. 4:6. 831-835. https://doi.org/10.5897/AJBM.9000686

15. Awojobi, O.N. (2014). The socio-economic implications of Boko Haram insurgency in the NorthEast of Nigeria. International Journal of Innovation and Scientific Research, 11(1), 144-150.

16. Bajpay, K. (2003). “The idea of human security”, International Journal of Studies, Vol.40,m No.3, pp.195-228.

17. Balami, D.H., Ahmed, F.F. \& Yusuf, A.B. (2016). The imperative of peace and security for the attainment of inclusive growth in Nigeria. European Journal of Research in Social Sciences. 4, 82-93. 
18. Bartolotta, C. (2011). Terrorism in Nigeria: The rise of BokoHaram. The Whitehead Journal of Diplomacy and International relations, 5(1), 44-57.

19. Berkowitz, L. (1989). 'Frustration-Aggression hypothesis: Examination and reformulation', Psychological Bulletin, 106(1):59-73 https://doi.org/10.1037/0033-2909.106.1.59

20. Blomberg, S.B., Hess, G.D., Orphanides, A. (2004). "The macroeconomic consequences of terrorism”. Journal of Monetary Economics. 51, 1007-1032. https://doi.org/10.1016/j.jmoneco.2004.04.001

21. Brown C (2007).The new terrorism debate alternatives.Journal of International Relations. 4(6): 28-43.

22. Buzan, B. (1997). Rethinking security after the cold war. Cooperation and Conflict. Retrieved from 5-28 https://doi.org/10.1177/0010836797032001001

23. Egugbo, C.C. (2016). Governance and sustainable peace in Nigeria. An International Multidisciplinary Journal, Ethiopia. 10(4), 41-55. https://doi.org/10.4314/afrrev.v10i4.3

24. Ekereke, A.S. (2013). The effects of Boko Haram insurgency and the school system; A case study of selected states in northern Nigeria. Science Journal of Sociology and Anthropology. Retrieved from http://www.sjpub.org/sjsa.html on November, 21th, 2013.

25. Ekundayo, W.J. (2015). National development in Nigeria and the indispensable lessons for Nigeria to learn from the Asian tigers. Journal of Good Governance and Sustainable Development in Africa. 2, 10-16.

26. $\quad$ Eme, O.I., \&Ibietan, J. (2012). The cost of Boko Haram activities in Nigeria. Arabian Journal of Business and Management Review (OMAN Chapter), 2(2), 10-32.

27. Golder B., Williams G. (2004). What is terrorism? problems of legal definition. UNSW Law J. 27(2): 270-295.

28. Gries, T., Krieger, T., \&Meierrieks, D. (2011). Causal linkages between domestic terrorism and economic growth. Defence and Peace Economics. 22, $493-508$. https://doi.org/10.1080/10242694.2010.532943

29. Gupta, S. (2004). Fiscal consequences of armed conflict and terrorism in low and middle income countries.European Journal of Political Economy. $403-421$. https://doi.org/10.1016/j.ejpoleco.2003.12.001

30. Igbuzor, O. (2011). "Peace and security education: A critical factor for sustainable peace and national development”, International Journal of Peace and Development Studies, $\quad 2(1), 1-7$. https://doi.org/10.5897/IJPDS.9000026

31. Iheanacho, E. N. (2014). National development planning in Nigeria: an endless search for appropriate development strategy. International Journal of Economic Development Research and Investment, 5(2) 49-59.

32. Joseph, O. (2014). National development strategies: Challenges and options. International Journal of Humanities and Social Science Invention, 3, 51-58.

33. Kamta, F.N., Azadi, H., \& Scheffron, J. (2020). The root causes of the crisis in northeast Nigeria: Historical, socioeconomic and environmental dimension. Mediterranean Journal of Social Sciences. 11, 95104. https://doi.org/10.36941/mjss-2020-0033

34. Lawal, T. \&Oluwatoyin, A. (2011). National development in Nigeria: Issues, challenges and prospects. Journal of Public Administration and Policy Research, 3(9), $237-241$. https://doi.org/10.5897/JPAPR11.012

35. Majekodunmi, A. (2015). Terrorism and counter-terrorism in contemporary Nigeria: Understanding the emerging trends. Journal of Policy and Development Studies. 9, 128-145.

36. Mapolisa, T., \&Matseketsa, B. (2013). The effects of terrorism on international peace and security and educational systems in Africa and beyond- A new millennium perspective. International Journal of Advanced Research. 1, 694-710.

37. Michael, S. (2007). Terrorism a socio-economic and political phenomenon with special reference to Pakistan. Journal of Management and Social Sciences. 3, 35-46.

38. Nwafor, H.A. (2012). Peace education and national development: A critical appraisal. Journal of Economics and Sustainable Development. 3, 131-135.

39. Obi, C. (2015). Challenges of insecurity and terrorism in Nigeria: Implication for national development.OIDAInternational Journal of Sustainable Development, 12-18.

40. Odoh, E. \& Innocent E.O. (2014). Role of the youths in national development. Singaporean Journal of Business Economics, and Management Studies, 3(2), 164-181. 
41. Odunola, A. \&Kolade, A. (2012). Empowering national development in Nigeria through appropriate national communication policy. Arabian Journal of Business and Management Review, 2(3),64-76.

42. Oghator, E. \&Okobo, R. (2000). Towards sustainable development in less developed countries: Foreign assistance revisited. The Nigerian Journal of Administrative Science, 5 (10): 201-208.

43. Okafor, E. E. (2011). Youth unemployment and implication for stability of democracy in Nigeria. Journal of Sustainable Development in Africa, 13(1), 358-373.

44. Olanrewaju, J.S. (2015). Globalization of terrorism: A case study of boko-haram in Nigeria. International Journal of Politics and Good Governance. 6, 1-22.

45. Omale, J.O. (2013). Terrorism and counter terrorism in Nigeria: Theoretical paradigms and lessons for public policy. $\quad$ Canadian Social $\quad$ Science. $\quad 9(3): \quad$ 96-103. http://dx.doi.org/10.3968/j.css.1923669720130903.2916

46. Omede, J. \&Omede, A. (2015). Terrorism and insecurity in Nigeria: Moral values and religious education as panaceas. Journal of education and Practice. 6, 120-126.

47. Onah, V. C. (2005). Democratic governance and crisis of development in Nigeria. American Journal of International Politics and Development Studies, 1 (1): 129-137.

48. Ovaga, K.H. (2018). The socio-economic implications of Boko Haram activities in northern Nigeria. Review of Public Administration and Management. 1, 19-37.

49. Sampon, I.T. \& Onuoha, F.O. (2011). "Forcing the horse to drink or making it realise its thirst? Understanding the enactment of anti-terrorism legislation in Nigeria," Perspectives on Terrorism. 5, 3-4. https://www.jstor.org/stable/26298522

50. Smith, A.G. (2004). From words to action: Exploring the relationship between a group's value references and its likelihood of engaging in terrorism. Studies in Conflict \& Terrorism.27, 409-37. https://doi.org/10.1080/10576100490483679

51. Tavares, J. (2004). The open society assesses its enemies: Shocks, disasters and terrorist attacks. Journal of Monetary Economics. 51, 1039-1070. https://doi.org/10.1016/j.jmoneco.2004.04.009

52. Tichaona, M. (2013).The effects of terrorism on international peace and security and educational systems in Africa and beyond- A new millennium perspectives, International Journal of Advanced

Research. 1, 694-710.

53. Ucha, C. (2010). "Poverty in Nigeria:Some dimensions and contributing factors (June). Global Majority E-Journal. 1:1.

54. Uche, E. (2019). Development plans and policies in Nigeria: Observed impediments and practical best alternatives. International Journal of Research and Scientific Innovation. VI, 27-36.

55. Udama, R. A. (2013). "Understanding Nigeria terrorism, its implications to national peace, security, unity and sustainable development: A discuss.” Journal of Humanities and Social Science. 8(5), 100-115.

56. Udu, L.E., \& Edeh, J.N. (2019). Implication of terrorism and insurgency for sustainable socioeconomic development in Nigeria. IOSR Journal of Humanities and Social Science, 24(5), 18-31.

57. Umukoro, N. (2014). Democracy and inequality in Nigeria. Journal of Developing Societies. 30(1), 1-24. https://doi.org/10.1177/0169796X13516340

58. Usman, S.A. (2014). Unemployment and poverty as sources and consequence of insecurity in Nigeria: The Boko Haram insurgency revisited. African Journal of Political Science and International Relations. 9(3), 90-99. https://doi.org/10.5897/AJPSIR2014.0719

59. Yildirim, J., \&Ocal, N. (2013). Analysing the determinants of terrorism in Turkey using geographically weighted regression. Defense and Peace Economics. 24, $195-209$. https://doi.org/10.1080/10242694.2012.695034

60. Zakaria, M., Jun, W., \& Ahmed, H. (2018). Effect of terrorism on economic growth in Pakistan: Am empirical analysis. Economics Research EkonomskaIstrazivanja. 32, 1794-1812. https://doi.org/10.1080/1331677X.2019.1638290 